\title{
SPATIAL VARIABILITY OF THE GRANULOMETRIC FRACTIONS AND CHEMICAL ATTRIBUTES OF A SANDY SOIL UNDER A NO-TILLAGE SYSTEM
}

\author{
Osvaldo Guedes Filho1, ${ }^{1,}$ Sidney Rosa Vieira²; Glécio Machado Siqueira3; Marcio Koiti Chiba² \\ ${ }^{1}$ Assistant Professor, Paraná Federal University, UFPR -Jandaia do Sul Advanced Campus. Jandaia do Sul/PR, Brazil. \\ ${ }^{2}$ Scientific researcher, Agronomic Institute, IAC. Campinas/SP, Brazil. ${ }^{3}$ Assistant Professor, Maranhão Federal University, \\ UFMA - Geosciences Department. São Luís/MA, Brazil. \\ ${ }^{*}$ Corresponding author: osvaldoguedes@ufpr.br
}

ABSTRACT: The soils presented heterogeneity of its chemical and physical attributes even in areas considered uniform. The aim of this study was to analyze the spatial variability of the granulometric fractions and of the chemical attributes of a sandy soil under no-tillage system. The work was developed at the Regional Pole of Agribusiness Technology Development from Paulista northwest located in Votuporanga/SP, on an experimental area under no-tillage system. The area measures about 1 ha with the sampling grid of $10 \times 10 \mathrm{~m}$. The area soil is a Red Latosol. The granulometric fractions and the chemical attributes of this soil were determined at a depth of 0-0.10 and 0.10-0.20 m. The data were analyzed using descriptive statistics and geostatistics tools for the spatial variability modeling. Most of the variables presented a moderate degree of spatial dependence. The granulometric fractions, water $\mathrm{pH}, \mathrm{KCl} \mathrm{pH}, \mathrm{Ca}, \mathrm{Na}, \mathrm{H}, \mathrm{and} \mathrm{C}$ presented small variations of its levels in the two analyzed depths. The granulometric fractions and the soil chemical attributes did not present spatial relations between them. There was similarity of the boundary lines for the attributes related to the soil acidic reaction $(\mathrm{pH}, \mathrm{Al}$, and $\mathrm{H})$. The spatial stability in the found depth for the granulometric fractions and soil chemical attributes demonstrate the potential management for the area in specific zones.

Key words: soil texture, geostatistics, soil management.

\section{VARIABILIDADE ESPACIAL DAS FRAÇÕES GRANULOMÉTRICAS E DE ATRIBUTOS QUÍMICOS DE UM SOLO ARENOSO SOB SISTEMA PLANTIO DIRETO}

RESUMO: Os solos apresentam heterogeneidade dos seus atributos químicos e físicos mesmo em áreas consideradas uniformes. O objetivo deste trabalho foi analisar a variabilidade espacial das frações granulométricas e de atributos químicos de um solo arenoso sob sistema plantio direto. O trabalho foi desenvolvido no Pólo Regional de Desenvolvimento de Tecnologias do Agronegócio do Noroeste Paulista localizado em Votuporanga/SP, em área experimental sob sistema plantio direto. A área mede cerca de 1 ha com grade de amostragem de $10 \times 10 \mathrm{~m}$. O solo da área é um Latossolo Vermelho. Foram determinadas as frações granulométricas e os atributos químicos deste solo na profundidade de 0-0,10 e 0,10-0,20 m. Os dados foram analisados pela estatística descritiva e por ferramentas de geoestatística para modelagem da variabilidade espacial. A maioria das variáveis apresentou moderado grau de dependência espacial. As frações granulométricas, $\mathrm{pH}$ água, $\mathrm{pH} \mathrm{KCl}, \mathrm{Ca}, \mathrm{Na}, \mathrm{H}$ e C apresentaram pequenas variações dos seus teores nas duas profundidades analisadas. As frações granulométricas e os atributos químicos do solo não apresentaram relações espaciais entre si. Houve similaridade das linhas de contorno para os atributos relacionados à reação ácida do solo $(\mathrm{pH}, \mathrm{Al}$ e H). A estabilidade espacial em profundidade encontrada para as frações granulométricas e atributos químicos do solo demonstram o potencial de manejo da área em zonas específicas.

Palavras-chave: textura do solo, geoestatística, manejo do solo. 


\section{INTRODUCTION}

The sustainability of the agricultural production system largely depends on the adequate use of the natural resources, especially of the soil. In this context, the notillage system is considered the most important conservationist management system of soil for the grain production of modern agriculture, being cultivated in an area of approximately 117 million hectares worldwide, of which about 37 million hectares in Brazil (FEBRAPDP, 2016). The cover maintenance on the soil surface, protecting it from erosion and, additionally conserving the water in the soil and increasing the organic carbon levels are some of the benefits that make this a sustainable management system of the soil (Lal, 2000).

Although, the soils presented heterogeneity of its chemical and physical attributes even in areas considered uniform as their field characteristics such as: topography, vegetation and soil color (Cambardella et al., 1994). To minimize the effects of soil variability in cultures productivity has been used geospatial analysis tools so that, the agricultural production systems be optimized, with the intention to manage the spatial variability (Molin, 2000; Guedes Filho et al., 2010).

In determining this variability, geostatistics has been the most used tool, enabling the interpretation of the results based on the variability structure obtained in the semivariograms (Vieira, 2000; Vieira et al., 2002). From the geostatistical analysis, it has been possible to know the spatial variability of chemical and physical attributes of the soil under the soil management systems and of the cultures production (Souza et al., 2008; Zucoloto et al., 2011; Lima et al., 2014; Castione et al., 2015).

Due to the high spatial and temporal variability that the soil attributes may present (Carvalho et al, 2003), the knowledge of the spatial variability of the granulometric fractions becomes important in relation to the surface flow and water movement in soil (Kitamura et al., 2007). While, the knowledge of the spatial variability of soil chemical properties is important because, it can provide subsidies for rationalization of the land use and of the inputs (Montezano et al., 2006; Vieira et al., 2009).

The aim of this work was to analyze the spatial variability of the granulometric fractions and of the chemical attributes of a sandy soil in experimental plots under notillage system.

\section{MATERIAL AND METHODS}

The experiment was developed in an area located in the Regional Pole of Agribusiness Technology Development from Paulista northwest located in Votuporanga/SP $\left(20^{\circ} 20\right.$ 'S and $49^{\circ} 58^{\prime} \mathrm{W}$ ).

The area was cultivated under no-tillage system and measures about $90 \mathrm{~m}$ wide by $100 \mathrm{~m}$ length. The sampling grid was $10 \times 10$ $\mathrm{m}$, totaling 110 sampling points. The soil of the area is classified as eutrophic Red Latosol of sandy texture (EMBRAPA, 2013), with an altitude of about 525 meters, the average temperature of $24{ }^{\circ} \mathrm{C}$ and average annual rainfall of $1,300 \mathrm{~mm}$, irrigated by a central pivot. The regional climate, according to the Köppen classification, is Aw, defined as 
tropical humid with the rainy season in summer and dry in winter.

For the determinations of the granulometric fractions and chemical attributes were collected samples of the deformed soil in each of the sampling points in the depths of $0-0.10$ and $0.10-0.20 \mathrm{~m}$. The granulometric fractions were determined by the pipette method (EMBRAPA, 1997). The soil chemical attributes (water $\mathrm{pH}, \mathrm{KCl} \mathrm{pH}$, calcium, magnesium, potassium, sodium, sulfur, hydrogen, aluminum and organic carbon) were determined according to the methodology described in Raij et al. (2001).

The data were analyzed using descriptive statistics through the following parameters: average, variance, the coefficient of variation, skewness, and kurtosis, which allowed verifying the existence of central tendency and data dispersion.

To characterize the spatial variability of the granulometric fractions and of the soil chemical attributes, the data were analyzed using geostatistical methods by calculating the semivariograms (Vieira, 2000), from the assumptions of the existence of intrinsic stationarity hypothesis. The spatial autocorrelation among neighbors sites was calculated by the semivariance $\mathrm{y}(\mathrm{h})$ according to the equation 1 :

$$
\gamma^{*}(h)=\frac{1}{2 N(h)} \sum_{i=1}^{N(h)}\left[Z\left(x_{i}\right)-Z\left(x_{i}+h\right)\right]^{2}
$$

wherein $N(h)$ is the number of measured pairs values $Z\left(x_{i}\right), Z\left(x_{i}+h\right)$, separated by a vector $h$.

The calculation of the equation 1 generates values of $y(h)$ corresponding to distances $h$ and, according to Vieira (2000), it is expected that measurements carried at nearby locations look more like to each other than those separated by large distances. This way the $y(h)$ increases with the distance to a maximum value from which stabilizes at a corresponding level to the spatial dependence distance limit, which is the range.

The adjustment of the experimental models to the semivariogram were based on the higher value of the coefficient of determination and the lowest value of the square root of the average error, and the choice of the best fit was carried out using the technique known as "jack-knifing" according to Vieira et al. (2002). From the adjustment of a mathematical model to the data, the semivariogram parameters were defined: nugget effect $\left(C_{0}\right)$, which is the value of $y$ when $\mathrm{h}=0$; range of the spatial dependency (a), which is the distance where $y(h)$ remains approximately constant, after increasing with the increase of $h$; and level $\left(C_{0}+C_{1}\right)$ which is the value of $y(h)$ from the range and that approximates of the data variance, if it exists.

To express the spatial dependence of a variable was used the degree of spatial dependence (DD), which measures the proportion of the nugget effect $\left(\mathrm{C}_{0}\right)$ regarding the level $\left(C_{0}+C_{1}\right)$ and can be calculated by the equation 2 :

$$
D D=\left(\frac{C_{0}}{C_{0}+C_{1}}\right) \cdot 100
$$

According to Cambardella et al. (1994), the DD can be used to classify the spatial dependence as strong ( $\mathrm{DD}<25 \%$ ), moderate ( $26 \%<\mathrm{DD}<75 \%$ ) and weak (DD > $75 \%$ ).

When proved the spatial autocorrelation between the samples through the analysis of the semivariograms, to reflect the spatial distribution of the studied attributes was 
carried out the kriging interpolation technique (Eq. 3), which also allows the values estimation for unsampled locations without trend and with minimum variance. With the interpolated values were created isoline maps. This technique uses the spatial dependence between neighbor samples, expressed in the semivariogram to estimate values at any position within the area (Vieira, 2000).

$$
Z\left(x_{0}\right)=\sum_{i=1}^{N} \lambda_{1} Z(x i)
$$

The geostatistical analysis was carried out with the set of GEOSTAT software (Vieira et al., 2002). The construction of variability maps was carried out using SURFER 11.0 software (Golden Software, 2012).

\section{RESULTS AND DISCUSSION}

Table 1 shows the data descriptive statistics for the studied variables. The coefficients of skewness and kurtosis give an idea about the shape of the data frequency distribution curve and according to the adopted calculation procedure, the closer to zero are their values, closer to a normal type distribution.

Table 1. Descriptive statistics for the granulometric fractions and soil chemical attributes.

\begin{tabular}{|c|c|c|c|c|c|c|c|c|}
\hline Variable & Average & Variance & S.D. & C.V. & Minimum & Maximum & Skewness & Kurtosis \\
\hline \multicolumn{9}{|c|}{$0-0,10 \mathrm{~m}$} \\
\hline Sand (\%) & 84.04 & 2.46 & 1.57 & 1.87 & 78.00 & 87.00 & -0.62 & 0.89 \\
\hline Silt (\%) & 7.20 & 4.27 & 2.07 & 28.71 & 1.00 & 13.00 & 0.29 & 1.94 \\
\hline Clay (\%) & 8.76 & 3.20 & 1.79 & 20.42 & 4.00 & 13.00 & 0.23 & 0.75 \\
\hline Water $\mathrm{pH}$ & 5.85 & 0.19 & 0.43 & 7.43 & 4.60 & 6.60 & -0.45 & -0.41 \\
\hline $\mathrm{KCl} \mathrm{pH}$ & 4.85 & 0.25 & 0.50 & 10.35 & 3.60 & 5.70 & -0.49 & -0.53 \\
\hline $\mathrm{Ca}\left(\mathrm{mmol}_{\mathrm{c}} \mathrm{dm}^{-3}\right)$ & 2.70 & 1.18 & 1.09 & 40.23 & 1.20 & 6.00 & 0.88 & 0.25 \\
\hline $\mathrm{Mg}\left(\mathrm{mmol}_{\mathrm{c}} \mathrm{dm}^{-3}\right)$ & 0.46 & 0.06 & 0.25 & 55.14 & 0.00 & 2.10 & 2.96 & 16.47 \\
\hline $\mathrm{K}\left(\mathrm{mmol}_{\mathrm{c}} \mathrm{dm}^{-3}\right)$ & 0.15 & 0.00 & 0.06 & 40.44 & 0.05 & 0.42 & 1.67 & 4.74 \\
\hline $\mathrm{Na}\left(\mathrm{mmol}_{\mathrm{c}} \mathrm{dm}^{-3}\right)$ & 0.03 & 0.00 & 0.02 & 53.48 & 0.00 & 0.08 & 0.95 & 1.01 \\
\hline $\mathrm{Al}\left(\mathrm{mmol}_{\mathrm{c}} \mathrm{dm}^{-3}\right)$ & 0.06 & 0.01 & 0.12 & 191.00 & 0.00 & 0.90 & 3.95 & 23.15 \\
\hline $\mathrm{H}\left(\mathrm{mmol}_{\mathrm{c}} \mathrm{dm}^{-3}\right)$ & 1.21 & 0.26 & 0.51 & 42.22 & 0.30 & 2.90 & 0.93 & 0.93 \\
\hline $\mathrm{C}(\%)$ & 0.57 & 0.01 & 0.12 & 20.41 & 0.30 & 0.90 & 0.53 & 0.13 \\
\hline \multicolumn{9}{|c|}{$0,10-0,20 \mathrm{~m}$} \\
\hline Sand (\%) & 82.78 & 20.32 & 4.51 & 5.45 & 39.00 & 86.00 & -8.63 & 84.03 \\
\hline Silt (\%) & 7.36 & 4.84 & 2.20 & 29.91 & 2.00 & 19.00 & 1.21 & 6.73 \\
\hline Clay (\%) & 9.86 & 13.23 & 3.64 & 36.88 & 4.00 & 42.00 & 6.48 & 56.88 \\
\hline Water $\mathrm{pH}$ & 6.02 & 0.16 & 0.40 & 6.67 & 4.90 & 6.90 & -0.29 & -0.09 \\
\hline $\mathrm{KCl} p \mathrm{H}$ & 5.00 & 0.23 & 0.48 & 9.60 & 3.80 & 6.10 & -0.17 & -0.33 \\
\hline $\mathrm{Ca}\left(\mathrm{mmol}_{\mathrm{c}} \mathrm{dm}^{-3}\right)$ & 2.81 & 0.93 & 0.97 & 34.40 & 1.30 & 6.60 & 0.83 & 1.12 \\
\hline $\mathrm{Mg}\left(\mathrm{mmol}_{\mathrm{c}} \mathrm{dm}^{-3}\right)$ & 0.54 & 0.22 & 0.46 & 86.17 & 0.10 & 5.00 & 8.29 & 80.05 \\
\hline $\mathrm{K}\left(\mathrm{mmol}_{\mathrm{c}} \mathrm{dm}^{-3}\right)$ & 0.10 & 0.00 & 0.03 & 31.90 & 0.03 & 0.20 & 0.33 & -0.34 \\
\hline $\mathrm{Na}\left(\mathrm{mmol}_{\mathrm{c}} \mathrm{dm}^{-3}\right)$ & 0.03 & 0.00 & 0.02 & 53.09 & 0.00 & 0.07 & 0.51 & -0.62 \\
\hline $\mathrm{Al}\left(\mathrm{mmol}_{\mathrm{c}} \mathrm{dm}^{-3}\right)$ & 0.04 & 0.01 & 0.09 & 232.70 & 0.00 & 0.50 & 3.24 & 11.33 \\
\hline $\mathrm{H}\left(\mathrm{mmol}_{\mathrm{c}} \mathrm{dm}^{-3}\right)$ & 1.07 & 0.21 & 0.46 & 43.00 & 0.40 & 2.70 & 1.26 & 2.16 \\
\hline $\mathrm{C}(\%)$ & 0.53 & 0.01 & 0.12 & 22.39 & 0.20 & 0.90 & 0.42 & 1.11 \\
\hline
\end{tabular}

SD - standard deviation; CV - coefficient of variation; Ca- calcium; Mg - magnesium; K - potassium; Na - sodium; Al - aluminium; $\mathrm{H}$ - hidrogen; C organic carbon. 
The results of semivariographic analysis can be observed in Table 2. All the variables that presented spatial dependence, in both depths, have adjusted to the spherical model. The spherical model has been reported in the literature as the most common adjustment to the soil and plant data (Grego e Vieira, 2005; Siqueira et al., 2008; Guedes Filho et al., 2010; Vieira et al., 2010).
In the 0-0.10 $\mathrm{m}$ layer, $\mathrm{Mg}$ and $\mathrm{K}$ had Pure Nugget Effect (PNE) and in the 0.10-0.20 m layer was the $\mathrm{K}$ and Al. Probably, as this is a very movable soil ion, associated to the fact that the texture is sandy, has not been found a spatial dependence structure for $\mathrm{K}$ chemical attribute.

Table 2. Semivariogram adjustment parameters for the granulometric fractions and soil chemical attributes.

\begin{tabular}{|c|c|c|c|c|}
\hline Variable & $\mathrm{C}_{0}$ & $\mathrm{C}_{1}$ & $r(m)$ & DD\% \\
\hline \multicolumn{5}{|c|}{$0-0,10 \mathrm{~m}$} \\
\hline Sand (\%) & 1.0 & 1.65 & 23.0 & 38 \\
\hline Silt (\%) & 1.6 & 2.54 & 26.01 & 39 \\
\hline Clay (\%) & 1.4 & 1.90 & 21.0 & 42 \\
\hline Water pH & 0.1 & 0.1 & 67.4 & 50 \\
\hline $\mathrm{KCl} \mathrm{pH}$ & 0.16 & 0.12 & 78.4 & 57 \\
\hline $\mathrm{Ca}\left(\mathrm{mmol}_{\mathrm{c}} \mathrm{dm}^{-3}\right)$ & 0.94 & 0.24 & 26.1 & 80 \\
\hline $\mathrm{Mg}\left(\mathrm{mmol}_{\mathrm{c}} \mathrm{dm}^{-3}\right)$ & \multicolumn{4}{|c|}{ PNE } \\
\hline $\mathrm{K}\left(\mathrm{mmol}_{\mathrm{c}} \mathrm{dm}^{-3}\right)$ & \multicolumn{4}{|c|}{ PNE } \\
\hline $\mathrm{Na}\left(\mathrm{mmol}_{\mathrm{c}} \mathrm{dm}^{-3}\right)$ & 0.00014 & 0.00017 & 36.5 & 45 \\
\hline $\mathrm{Al}\left(\mathrm{mmol}_{\mathrm{c}} \mathrm{dm}^{-3}\right)$ & 0.009 & 0.007 & 21.9 & 56 \\
\hline $\mathrm{H}\left(\mathrm{mmol}_{\mathrm{c}} \mathrm{dm}^{-3}\right)$ & 0.07 & 0.21 & 27.4 & 25 \\
\hline $\mathrm{C}(\%)$ & 0.003 & 0.012 & 40.1 & 20 \\
\hline \multicolumn{5}{|c|}{$0,10-0,20 \mathrm{~m}$} \\
\hline Sand (\%) & 12.1 & 15.3 & 23.0 & 44 \\
\hline Silt (\%) & 3.6 & 1.36 & 35.7 & 73 \\
\hline Clay (\%) & 4.6 & 12.4 & 23.0 & 27 \\
\hline Water pH & 0.08 & 0.08 & 46.8 & 50 \\
\hline $\mathrm{KCl} \mathrm{pH}$ & 0.11 & 0.11 & 40.7 & 50 \\
\hline $\mathrm{Ca}\left(\mathrm{mmol}_{\mathrm{c}} \mathrm{dm}^{-3}\right)$ & 0.65 & 0.35 & 64.4 & 65 \\
\hline $\mathrm{Mg}\left(\mathrm{mmol}_{\mathrm{c}} \mathrm{dm}^{-3}\right)$ & 0.12 & 0.16 & 23.0 & 43 \\
\hline $\mathrm{K}\left(\mathrm{mmol}_{\mathrm{c}} \mathrm{dm}^{-3}\right)$ & \multicolumn{4}{|c|}{ PNE } \\
\hline $\mathrm{Na}\left(\mathrm{mmol}_{\mathrm{c}} \mathrm{dm}^{-3}\right)$ & 0.00012 & 0.00014 & 45.7 & 46 \\
\hline $\mathrm{Al}\left(\mathrm{mmol}_{\mathrm{c}} \mathrm{dm}^{-3}\right)$ & \multicolumn{4}{|c|}{ PNE } \\
\hline $\mathrm{H}\left(\mathrm{mmol}_{\mathrm{c}} \mathrm{dm}^{-3}\right)$ & 0.085 & 0.12 & 23.0 & 41 \\
\hline $\mathrm{C}(\%)$ & 0.003 & 0.014 & 23.0 & 86 \\
\hline
\end{tabular}

Ca- calcium; Mg - magnesium; $\mathrm{K}$ - potassium; $\mathrm{Na}$ - sodium; $\mathrm{Al}$ - aluminum; $\mathrm{H}$ - hydrogen; $\mathrm{C}$ - organic carbon; $\mathrm{C}_{0^{-}}$nugget effect; $\mathrm{C}_{1^{-}}$structured variance; $r$ - range; DD- Degree of spatial dependence; NE -pure nugget effect.

The nugget effect $\left(\mathrm{C}_{0}\right)$ reflects the variability not explained by the semivariogram for distances smaller than the separation distance between the samples (Vieira, 2000). In general, all attributes showed low nugget effect values, indicating a good spatial continuity of the data. However, comparatively, $\mathrm{Na}, \mathrm{Al}, \mathrm{H}$, and Corg in two depths had greater spatial continuity than other attributes, with exception to the $\mathrm{Al}$ ion, which presented pure nugget effect in layer 0.10-0.20m.

Most of the variables presented a degree of a moderate or strong spatial dependence, except for Ca (0-0.10 m) and Corg (0.10-0.20 $\mathrm{m})$ that presented weak spatial dependence. 
Curiously, the Corg attribute on the 0-0.10 m presented a strong degree of spatial dependence. Many studies have found a structure of spatial dependence classified as moderate or strong (Zanão Júnior et al., 2007; Vieira et al., 2009). This result is mainly important for being a sandy soil, where there is a higher probability of losing nutrients by leaching, associated with the high rainfall index of the region, which could result in a completely random distribution of the soil chemical attributes.

The range of spatial dependence expressed by the adjusted model is an important parameter for the interpretation of the semivariograms by indicating the maximum distance to where the sample points are correlated. The observed range values were high, showing that the used space in sampling was enough to express the spatial variability of the soil granulometric fractions and soil chemical attributes. The range values ranged from $21 \mathrm{~m}$ for clay to $67.4 \mathrm{~m}$ for the $\mathrm{pH}$ in the water layer $0-0.10 \mathrm{~m}$, while the lower layer, the range varied from $23 \mathrm{~m}$ (sand, clay, Mg, Al, and Corg) to $64.4 \mathrm{~m}$ (Ca). High range value for $\mathrm{Ca}$ was also observed by Vieira et al. (2009) using a sampling grid of $20 \times 20 \mathrm{~m}$. The lower range values were found for clay $(21.0 \mathrm{~m})$ and $\mathrm{Al}$ $(21.9 \mathrm{~m})$, both in the surface layer. Guedes Filho et al. (2010) also found the lower range values for Al using the same sampling grid of the present study.

The boundary maps for the studied variables are shown in Figures 1, 2, 3 and 4. It is verified by the visual analysis of boundary maps, the predominance of vivid spots and well defined for the granulometric fractions and soil chemical attributes. The maps of granulometric fractions silt and clay presented high similarity of boundary lines between them in the layer 0-0.10 m, while for the lower layer this similarity occurred between the sand and clay fractions (Fig. 1 and 3). In the comparison between depths, there was a wide variation of granulometric fractions, except for the decrease in the clay level in the 0.10-0.20 m layer. In 0-0.10 m almost the entire area had sand levels higher than $76 \%$, while in the layer 0.10-0.20 m values greater than $81 \%$. This explains the reduction in clay levels in this layer (Fig. 1 and 3).

The water $\mathrm{pH}, \mathrm{KCl} \mathrm{pH}, \mathrm{Al}$ and $\mathrm{H}$ chemical attributes, presented similarity of the spatial distribution between them, showing that the center-right of the area showed the highest $\mathrm{pH}$ values and smaller $\mathrm{Al}$ and $\mathrm{H}$ in the $0-0$ layer, $10 \mathrm{~m}$ (Fig. 2). There was some similarity between the maps of clay and Corg in the 0$0.10 \mathrm{~m}$ layer, coinciding the highest Corg values with higher clay values. However, were not observed similarities between the granulometric fractions and the other soil chemical attributes for the surface layer. Probably for being a soil with a high sand level (predominantly above 76\%), there was a low similarity to the chemical attributes, which are more dependent on the soil clay fraction.

In the 0.10-0.20 $\mathrm{m}$ layer, there was similarity of the distribution between the water $\mathrm{pH}, \mathrm{KCl} \mathrm{pH}, \mathrm{Na}$ and $\mathrm{H}$ (Fig. 4). Once again, the center-right part of the area presented the highest $\mathrm{pH}$ values and lower $\mathrm{Na}$ and $\mathrm{H}$. Regarding the central part of the area there was a spatial similarity between $\mathrm{H}$ and Corg, where the smaller $H$ values were coincident with the largest Corg. However, in this layer was not detected similarities between the granulometric fractions and the soil chemical attributes. 

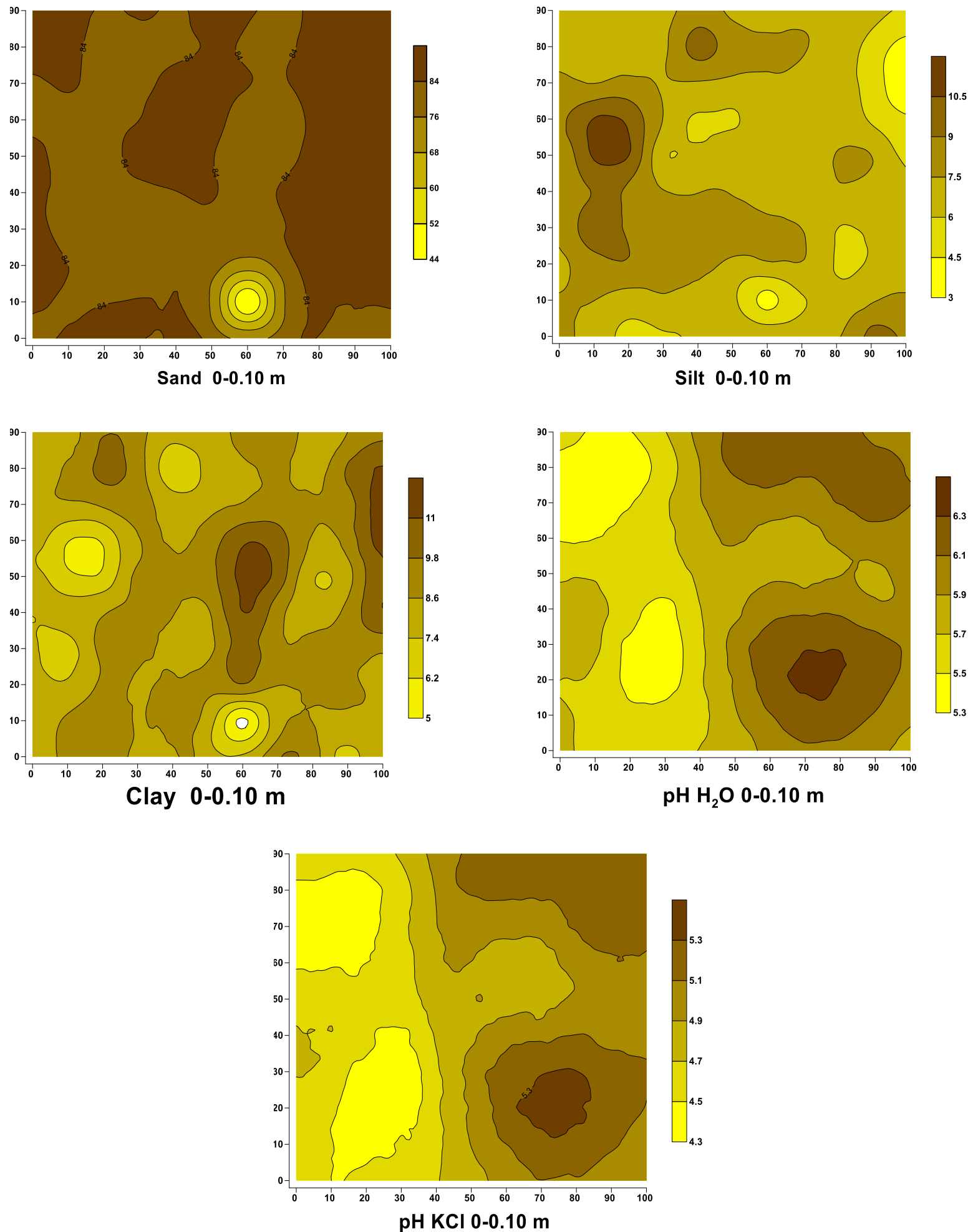

Figure 1. Boundary maps of the granulometric fractions and soil pH in 0-0.10 m layer. 

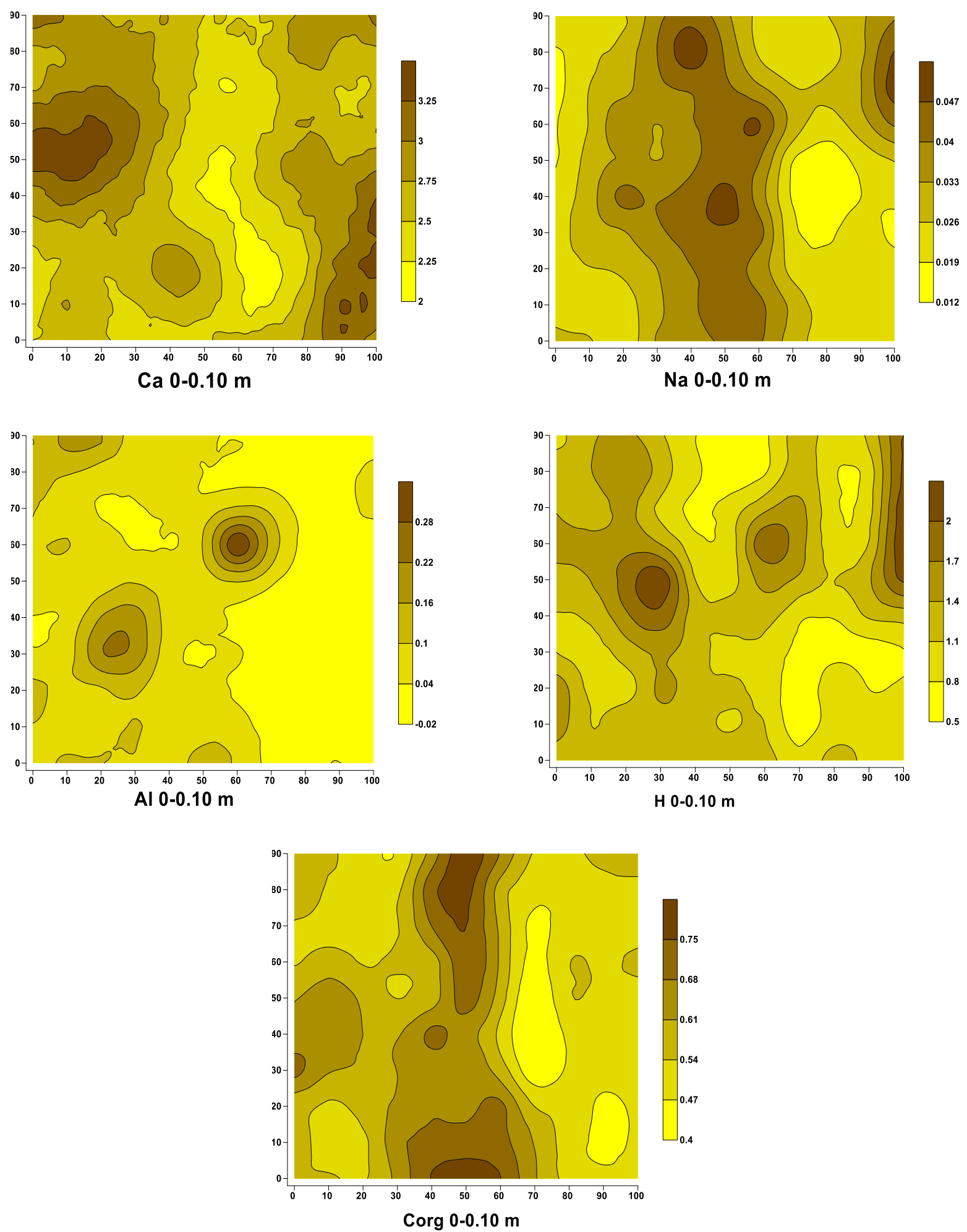

Figure 2. Boundary maps of soil chemical attribute in the 0-0.10 m layer. Ca- calcium; $\mathrm{Na}$ - sodium; Al - aluminum; $\mathrm{H}$ hydrogen; Corgi - organic carbon. 

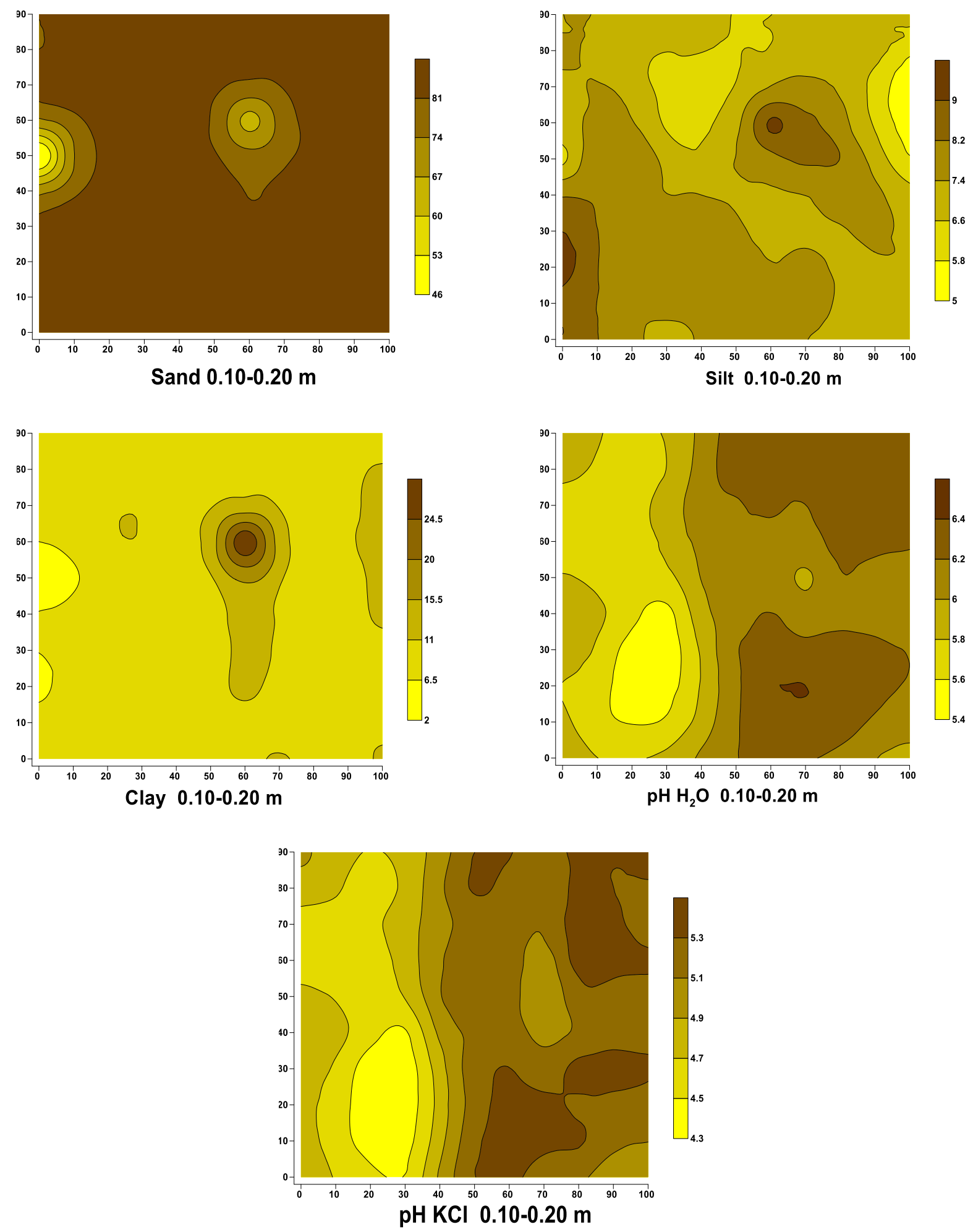

Figure 3. Boundary maps of the granulometric fractions and soil $\mathrm{pH}$ in the $0.10-0.20 \mathrm{~m}$ layer. 

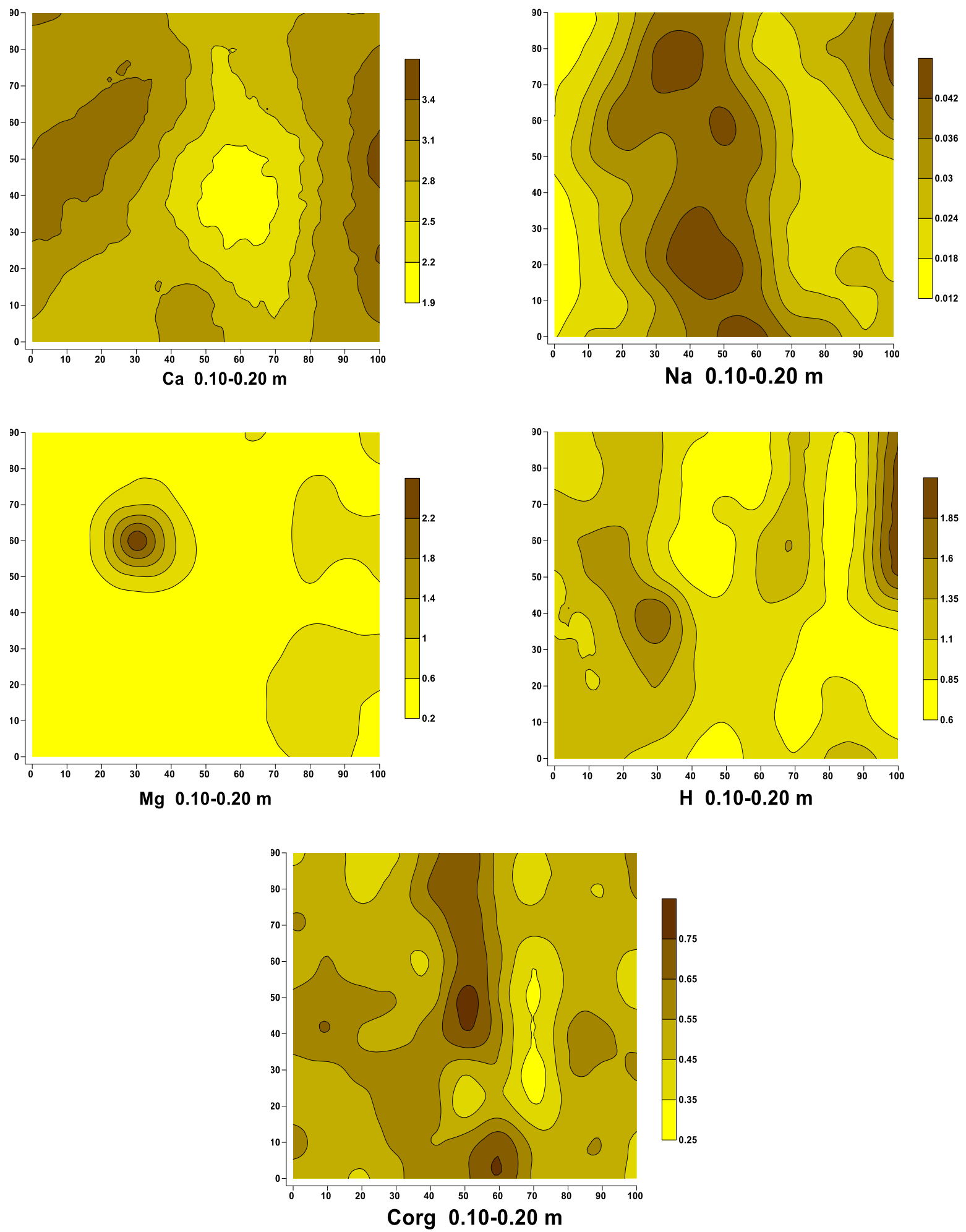

Figure 4. Boundary maps of soil chemical attribute in 0.10-0.20 m layer. Ca- calcium; Na - sodium; Mg - magnesium; $\mathrm{H}$ hydrogen; Corgi - organic carbon.

The soil granulometric fractions and the water $\mathrm{pH}, \mathrm{KCl} \mathrm{pH}, \mathrm{Ca}, \mathrm{Na}, \mathrm{H}$ and $\mathrm{C}$ chemical 
attributes presented stability in depth, showing the distribution of similar boundary lines in both depths analyzed. This shows the spatial dependence relation also in depth for these attributes. What makes this result important in relation to the management in specific zones, considering that the input application at the surface will attend the demands of both depths. Because it is a sandy and chemically poor soil, these results will be useful for the most rational management and the varied rates of fertilization in this area.

\section{CONCLUSION}

The granulometric fractions and the soil chemical attributes did not present spatial relations between them. There was similarity of the boundary lines for the attributes related to the soil acidic reaction $(\mathrm{pH}, \mathrm{Al}$, and $H)$. The spatial stability in the found depth for the granulometric fractions and soil chemical attributes demonstrate the management potential of the area in specific zones.

\section{REFERENCES}

Cambardella, C. A.; Moorman, T.B; Novak, J. M.; Parkin, T. B.; Karlen, D. L.; Turco, R. F.; Konopka, A. E. 1994. Field-scale variability of soil properties in Central lowa Soils. Soil Sc.Soc.Am.J.,58:1501-1511.

Carvalho, M.P.; Takeda, E. Y.; Freddi, O. S. 2003. Variabilidade espacial de atributos de um solo sob videira em Vitória Brasil. R.Bras.Ci.Solo,27:695-703.

Castione, G.A.F.; Souza, Z.M.; Silva, R.B.; Campos, M.C.C.; Cunha, J.M. 2015. Variabilidade espacial da textura do solo em área irrigada por pivô central em diferentes posições na paisagem. Revista Agro@mbiente, 9: 219-226.

EMBRAPA. 1997. Centro Nacional de Pesquisa de Solos (Rio de Janeiro, RJ). Manual de métodos de análise de solo. 2. ed. rev. atual. Rio de Janeiro, 1997. 212 p.

EMBRAPA. 2013. Centro Nacional de Pesquisa de Solos. Sistema brasileiro de classificação de solos. 3. ed. Rio de Janeiro, 2013. 306 p.

FEDERAÇÃO BRASILEIRA DE PLANTIO DIRETO NA PALHA. Á rea de plantio direto no Brasil. Disponível em: <http://www.febrapdp.org.br>. Acesso em 10 de setembro de 2016.

Grego, C.R.; Vieira, S.R. 2005. Variabilidade espacial de propriedades físicas do solo em uma parcela experimental. R. Bras. Ci. Solo, 29: 169-177.

Guedes Filho, O.; Vieira, S.R.; Chiba, M.K.; Nagumo, C.H. ; Dechen, S.C. F. 2010. Spatial and temporal variability of crop yield and some Rhodic Hapludox properties under notillage. Revista Brasileira de Ciência do Solo, v. 34, p. 1-14.

Julião, S.S.L.; Bona, D.A.O.; Fiedler, N.C.; Pereira, D.P. 2014. Distribuição espacial das frações granulométricas argila e areia total em um latossolo vermelho-amarelo. Revista Árvore, 38: 513-521.

Kitamura, A.E.; Carvalho, M.P.; Lima, C.F.R. 2007. Relação entre a variabilidade das frações granulométricas e a produtividade de feijoeiro sob plantio direto. R. Bras. Ci Solo, 31: 361-369.

Lal, R. 2000. Physical management of soils of the tropics: priorities for the 21th century. Soil Science, v.135, p.191-207.

Molin, J.P. 2000. Geração e interpretação de mapas de produtividade para agricultura de precisão. In: Borém, A. ed. Agricultura de 
precisão. Viçosa, Universidade Federal de Viçosa, p.237-257.

Montezano, Z.F.; Corazza, E.J.; Muraoka, T.2006. Variabilidade espacial da fertilidade do solo em área cultivada e manejada homogeneamente. R. Bras. Ci. Solo, 30: 839847.

Raij, B. van; Andrade, J.C.; Cantarella, H.; Quaggio, J.A. 2001. Análise química para avaliação da fertilidade de solos tropicais. Campinas, Instituto Agronômico, 2001. 285p.

Siqueira, G.M.; Vieira, S.R.; Ceddia, M.B. 2008. Variabilidade espacial de atributos físicos do solo determinados por métodos diversos. Bragantia, 67: 693-699.

Souza, E.R.; Montenegro, A.A.S.; Montenegro, S.M.G.L.; Santos, T.E.M.; Andrade, T.S.; Pedrosa, E.R. 2008. Variabilidade espacial das frações granulométricas e da salinidade em um Neossolo Flúvico do semi-árido. Ciência Rural, 38: 698-704.

SURFER. 1012. Surfer 11.0. Contouring and 3D surface mapping for scientist's engineers. User's Guide. New York: Golden Software.

Vieira, S.R.; Guedes Filho, O.; Chiba, M.K.; Mellis, E.V.; Dechen, S.C.F. ; De Maria, I.C. 2010. Variabilidade espacial dos teores foliares de nutrientes e da produtividade da soja em dois anos de cultivo em um latossolo vermelho. Revista Brasileira de Ciência do Solo, 34: 1503-1514.

Vieira, S.R.; Guedes Filho, O.; Chiba, M.K.; Cantarella, H. 2009. Spatial variability of soil chemical properties after coffee tree removal. Rev. Bras. Ciênc. Solo, 33: 1507-1514.

Vieira, S.R. 2000. Geoestatística em estudos de variabilidade espacial do solo. In: Novais, R.F.; Alvarez, V.H.; Schaefer, G.R. Eds. Tópicos em Ciência do Solo. Viçosa: Sociedade Brasileira de Ciência do Solo, 1: p.1-54.
Vieira, S.R.; Millete, J.; Topp, G.C.; Reynolds, W.D. 2002. Handbook for geoestatistical analysis of variability in soil and climate data. In: ALVAREZ, V.V.H.; SCHAEFER, C.E.G.R.; BARROS, N.F.; MELLO, J.W.V.; COSTA, J.M. Tópicos em Ciência do solo. Viçosa: Sociedade Brasileira de Ciência do Solo, v.2, 2002. p.145.

Warrick, A.W.; Nielsen, D.R. 1980. Spatial variability of soil physical properties in the field. In: HILLEL, D. ed. Applications of soil physics. New York: Academic, 1980. p.319344.

Zanão Júnior, L.A.; Lana, R.M.Q.; Guimarães, E.C. 2007. Variabilidade espacial do pH, teores de matéria orgânica e micronutrientes em profundidades de amostragem num latossolo vermelho sob semeadura direta. R. Ci. Rural, 37: 1000-1007.

Zucoloto, M.; Lima, J.S.S.; Coelho, R.I.; Quartezani. W.Z. 2011. Variabilidade espacial das frações granulométricas e da produção de bananeira 'Prata Anã'. IDESIA, 29: 47-52. 